\title{
Experimental study of As(V) adsorption onto different adsorbents
}

Zuzana Danková a ,

Alexandra Bekényiová $\mathrm{a}^{\mathrm{a}^{*}}$

Zdenka Lukáčová-Bujňáková a,

Zuzana Mitroová ${ }^{b}$,

Danka Gešperová a,

Iveta Štyriaková ${ }^{c}$,

Darina Štyriaková d,

Jaroslav Briančin a ,

Jana Tomčová ${ }^{a}$

${ }^{a}$ Institute of Geotechnics,

Slovak Academy of Sciences,

Watsonova 45,

04001 Košice, Slovakia

${ }^{b}$ Institute of Experimental Physics,

Slovak Academy of Sciences,

Watsonova 47,

04001 Košice, Slovakia

' State Geological Institute of Dionýz Štúr,

Regional Center Košice,

Jesenského 8,

04001 Košice, Slovakia

${ }^{d}$ Faculty of Mining, Ecology,

Process Control and Geotechnologies,

Technical University of Košice,

Park Komenského 15,

04200 Košice, Slovakia
The $\mathrm{As}(\mathrm{V})$ adsorption onto natural bentonite $(\mathrm{B})$, Fe enriched bentonite (FB) and synthetic magnetic particles (MP) from the aqueous solutions was investigated by batch as well as column tests. The natural materials did not show such good adsorption properties towards $\mathrm{As}(\mathrm{V})$ in the batch experiments as MP, whose $Q_{\max }$ was calculated to $23 \mathrm{mg} / \mathrm{g}$. However, in column experiments the adsorption effect of natural materials was comparable with MP. The model solution with the concentration $30 \mathrm{mg} \mathrm{As}(\mathrm{V}) / \mathrm{L}$ was percolated through the columns filled with the B and FB sample. After two cycles the $\mathrm{As}(\mathrm{V})$ concentration was lower than $2 \mathrm{mg} / \mathrm{L}$. The second series of columns were filled with $\mathrm{FB} / \mathrm{MP} / \mathrm{QS}$ and $\mathrm{B} / \mathrm{MP} / \mathrm{QS}$. Two cycles with the solution concentration of 50 and $100 \mathrm{mg} A s(\mathrm{~V}) / \mathrm{L}$ were performed. After the second cycle 74 and $100 \%$ of $\mathrm{As}(\mathrm{V})$ were removed by $\mathrm{FB} / \mathrm{MP} / \mathrm{QS}$ and $\mathrm{B} /$ $\mathrm{MP} / \mathrm{QS}$, respectively. In the third series two most effective columns were selected for the second percolation of $100 \mathrm{mg} \mathrm{As}(\mathrm{V}) / \mathrm{L}$ solution. While the adsorption effect of the QS/MP column decreased at 36\%, for the QS/B/MP column it was about $24 \%$. The first experimental study showed that natural materials should be used effectively as column fillers to fix finer magnetic particles. On the other hand, their selectivity towards $\mathrm{Cu}(\mathrm{II})$ and $\mathrm{Zn}(\mathrm{II})$ ions could be beneficial for regeneration of media used in the process of soil bioremediation.

Keywords: arsenic, bentonite, Fe-bentonite, magnetic particles

\footnotetext{
"Corresponding author. Email: avaskova@saske.sk
} 


\section{INTRODUCTION}

Subsequent toxic contamination of soils is one of the main environmental problems of urbanisation and industrialisation and has recently become a serious concern in the world. Toxic elements are generally non-biodegradable in the soil matrix. They can be transported and accumulated in sediments and agricultural products and pose a risk to the food safety and human health. Therefore, the remediation of environment with the aim of its decontamination is a global environmental interest.

The treatment of contaminated soils and sediments can be achieved by either physical or chemical methods. Although these techniques have been extensively applied in practice, they show some limitations, such as low efficiency and high cost. Therefore, the bioremediation has received a great deal of attention in recent years [1]. In the past many branches of industry in Slovakia produced a plenty of waste and in recent times a problem with contamination of soils and sediments due to the mobilisation of metals and metalloids from the waste dumping, mining works and heaps occurs. One of them is also a locality Krompachy, loaded by the metallurgical industry. The biological-chemical leaching and usage of resistant bacteria was applied for $\mathrm{Cu}(\mathrm{II}), \mathrm{Zn}(\mathrm{II})$ and $\mathrm{As}(\mathrm{V})$ removal from the contaminated samples of soils and sediments [2-4], and the effect of bioleaching in static and dynamic conditions was studied [5]. These first experiments have brought a new ecological way of contaminated soil treatment, but also the question of obtained leachates processing. The reverse immobilisation of toxic elements from the water environment after the bioleaching process could be realised by adsorption and precipitation onto selected mineral materials and synthetic adsorbents. Naturally occurring clays and clay minerals are of paramount importance in the field of environmental and waste management. To the universal usable materials belongs bentonite whose unique properties are determined from its structure. There are few significant deposits of bentonite in the East part of Slovakia (Kuzmice, Fintice, Lastovce) as well as in Central Slovakia (Stará Kremnička - Jelšový potok and Lieskovec). These bentonites are used for industrial purposes, and their geological, geotechnical and sorption properties are still studied by Slovak researchers for their wider utilisation $[6-14$.
Iron oxides as natural compounds of soils, sediments and environment containing water have a large specific surface area and are able to adsorb a significant amount of toxic ions. They represent dominant adsorbents because they could be also fine dispersed and used as surface coatings of other particles [15]. Magnetic properties allow their easier separation from water. The magnetite, hematite and maghemite particles could be synthetised by different chemical methods, including their modification by functional groups (carboxyl acid) to prevent their agglomeration. The review of the published results about magnetic particles and their nanomaterials as adsorbents of As(III), $\mathrm{As}(\mathrm{V})$ and other heavy metal ions was done by Pragnesh and Lakhan [16]. The natural goethite and hematite were studied as adsorbents of $\mathrm{Cu}$ (II) and $\mathrm{Zn}$ (II) from waters. The synthetic oxides were more efficient, especially for $\mathrm{Cu}$ (II) removal, what corresponds with their better surface properties in comparison with natural materials [17].

In this study the $\mathrm{As}(\mathrm{V})$ adsorption onto natural bentonites and synthetic magnetic particles from the aqueous solutions was investigated by batch tests as well as in dynamic conditions. The natural and synthetic materials were combined as bedding in column to achieve the effective filter which could be used for regeneration of media utilising in the bioremediation process.

\section{EXPERIMENTAL}

\section{Adsorbents}

The natural clay samples originated from the Slovak deposit - locality Stará Kremnička - Jelšový potok. Two bentonite samples were studied: bentonite (B) and $\mathrm{Fe}$-enriched bentonite (FB) from the same deposit. The FB sample was visually more ocherous in comparison with the $\mathrm{B}$ sample. The clay samples were dried at $40^{\circ} \mathrm{C}$ for $24 \mathrm{~h}$ and sieved to obtain two fractions of particles, below $0.5 \mathrm{~mm}$ and between $0.5-1 \mathrm{~mm}$. The chemical composition of the studied clay samples is presented in Table 1 .

The $\mathrm{Fe}_{3} \mathrm{O}_{4}$ magnetic particles were synthetised by chemical precipitation: $15.9 \mathrm{~g} \mathrm{FeCl}_{3}$ and $14.0 \mathrm{~g}$ $\mathrm{FeSO}_{4} \cdot 7 \mathrm{H}_{2} \mathrm{O}$ were dissolved in $100 \mathrm{~mL}$ of deionized water and heated under rigorous stirring up to $60^{\circ} \mathrm{C}$. During next heating at $90^{\circ} \mathrm{C} 50 \mathrm{ml}$ of $25 \% \mathrm{NH}_{4} \mathrm{OH}$ was added dropwise. The precipitate was heated and stirred for one hour to complete 
Table 1. Chemical composition of natural clay samples

\begin{tabular}{c|c|c|c|c|c|c}
\hline Sample & Annealing loss, $\%$ & $\mathbf{S i O}_{2}, \%$ & $\mathbf{A l}_{2} \mathbf{0}_{\mathbf{3}^{\prime}} \%$ & $\mathbf{M g 0}, \%$ & $\mathbf{C a 0}, \%$ & $\mathrm{Fe}_{2} \mathbf{0}_{\mathbf{3}^{\prime}} \%$ \\
\hline $\mathrm{FB}$ & 15.24 & 57.2 & 17.28 & 3.89 & 2.72 & 2.56 \\
\hline $\mathrm{B}$ & 13.98 & 57.9 & 19.66 & 2.64 & 2.1 & 2.15 \\
\hline
\end{tabular}

the reaction. Then it was separated magnetically and washed with $700 \mathrm{~mL}$ of hot deionized water to remove free ions. The slurry was then dried at room temperature. The sample was labelled as MP.

\section{Textural study}

Textural properties of natural samples were determined from the adsorption and desorption isotherms by the method of physical adsorption of nitrogen at $-196^{\circ} \mathrm{C}$ measured with a NOVA $1200 \mathrm{e}$ Surface Area \& Pore Size Analyzer (Quantachrome Instruments, USA). First, the studied samples were degassed at $100^{\circ} \mathrm{C}$ in a vacuum oven under a pressure lower than $2 \mathrm{~Pa}$ for $16 \mathrm{~h}$. The measured data were processed by the BET (Brunnauer-EmmetTeller) isotherm in the range of relative pressure $p / p_{0} 0.05-0.2$ to obtain the value of a specific surface area $\left(S_{\mathrm{A}}\right)[18]$. The values of the external surface $\left(S_{\text {ext }}\right)$ and the volume of micropores $\left(V_{\text {micro }}\right)$ were calculated from the $t$-plot using the Harkins-Jura standard isotherm [19]. The value of the total pore volume $\left(V_{\text {tot }}\right)$ was estimated from the maximum adsorption at relative pressure close to saturation pressure. The pore size distribution was obtained from the desorption isotherm using the $\mathrm{BJH}$ (Barrett-JoynerHalenda) method [20].

\section{Zeta potential}

The zeta potential (ZP) was measured using a Zetasizer Nano ZS (Malvern, Great Britain). The Zetasizer Nano measures the electrophoretic mobility of the particles, which is converted to the zeta potential using the Helmholtz-Smoluchowski equation built into the Malvern zetasizer software. The zeta potential of the samples (concentration of $2 \mathrm{~g} / \mathrm{L}$ ) was measured within a different $\mathrm{pH}$ range, which was adjusted by the addition of $\mathrm{NaOH}$ or $\mathrm{HNO}_{3}$.

\section{Adsorption experiments}

Model solutions of $\mathrm{As}(\mathrm{V})$ were prepared from $\mathrm{KH}_{2} \mathrm{AsO}_{4}$ (per analysis quality) and distilled water, in the concentration of 1000 and $100 \mathrm{mg} \mathrm{As}(\mathrm{V}) / \mathrm{L}$. The model solutions were diluted to the obtained different concentrations in the range $10-50 \mathrm{mg}$ $\mathrm{As}(\mathrm{V}) / \mathrm{L}$. The $\mathrm{pH}$ of the solution was treated by diluted $\mathrm{HNO}_{3}$ and $\mathrm{NaOH}$ to be 4. The adsorption experiments were performed as batch and column tests. The adsorbent dosage for batch experiments was $10 \mathrm{~g} / \mathrm{L}$ for the clay samples and $1 \mathrm{~g} / \mathrm{L}$ for a magnetic adsorbent. The suspensions of the model solution and the dosed adsorbents were shaken in a rotary shaker in polyethylene bottles at laboratory temperature $\left(20^{\circ} \mathrm{C}\right)$ for $24 \mathrm{~h}$ at $30 \mathrm{rpm}$. The products were separated by filtration and the filtrates were analysed for the residual As content by atomic absorption spectroscopy (AAS). The adsorption experiments were done duplicate. The adsorption data were fitted with the Langmuir equation [21-22], providing the parameters of adsorption $\left(Q_{\max }\right.$ maximum equilibrium sorption capacity; $Q_{t}$, theoretical sorption capacity; $R^{2}$, coefficient of determination; $K_{\mathrm{L}}$, Langmuir adsorption constant), which were used for the comparison of $\mathrm{As}(\mathrm{V})$ adsorption affinity to natural clays and synthetic magnetite.

For the dynamic regime, $5 \mathrm{~g}$ of the sample (quartz sand or quartz sand with clay/magnetic particles) was filled into the glass column with a fritted end. The synthetic magnetic particles are very fine, therefore another bearer in the column is required. Quartz sand is a cheap, stable material with a good permeability and could be used to fix fine magnetic particles in the column. Natural quartz sand with $0.5 \mathrm{~g}$ of the synthetised sample as middle bedding was used in the column. The solution of the $\mathrm{As}(\mathrm{V})$ concentration in the range $30-100 \mathrm{mg} / \mathrm{L}$ was percolated through the columns. The experiments were done duplicate. The effect of $\mathrm{As}(\mathrm{V})$ retention and the possibility to use column fillers more times was studied. Finally, the effect of adsorbents combination in the column beddings on $\mathrm{As}(\mathrm{V})$ adsorption was also tested.

\section{RESULTS AND DISCUSSION}

\section{Textural analysis}

The natural clay samples showed a similar run of adsorption/desorption isotherms with the difference in 


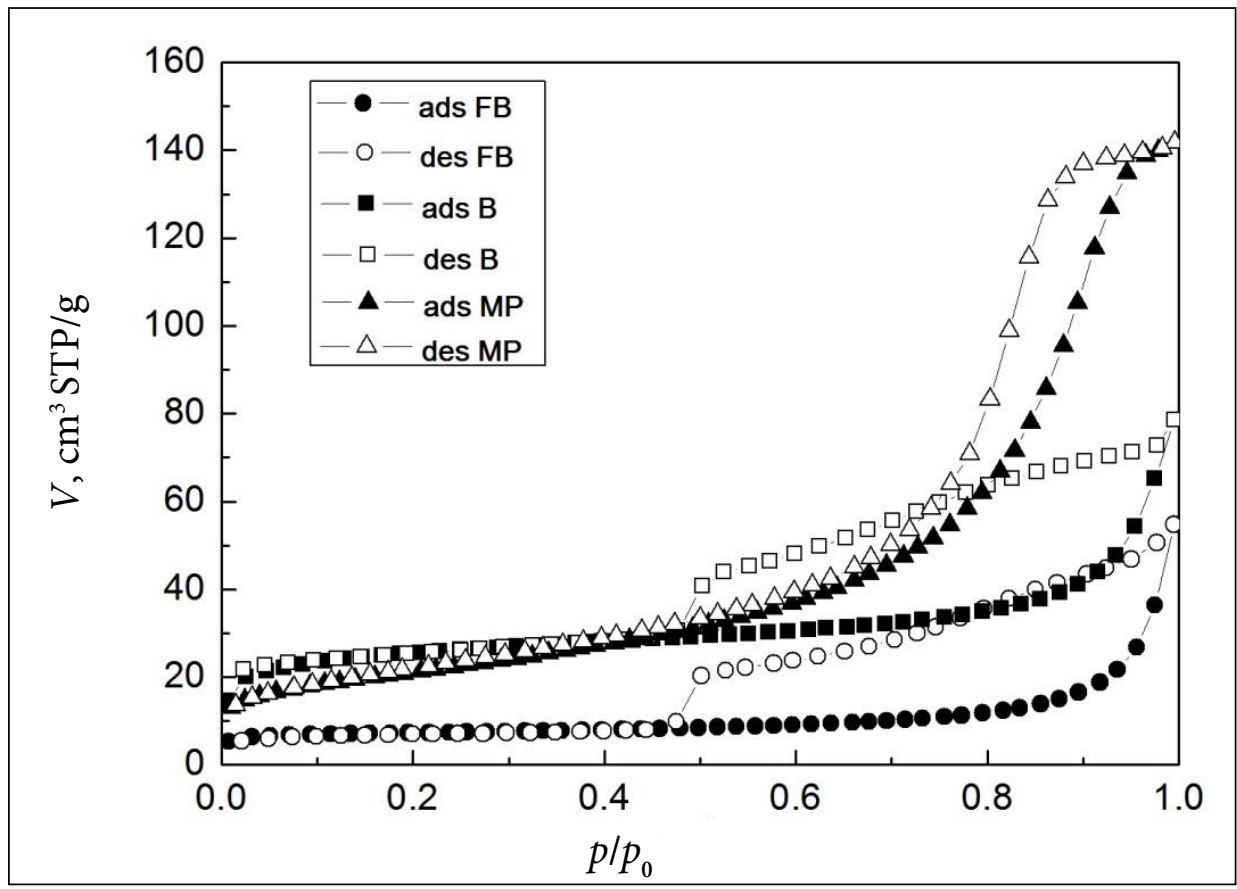

Fig. 1. Adsorption/desorption isotherms of the studied bentonite samples and magnetic particles

the volume of adsorbed/desorbed gas (Fig. 1). Lower values of the adsorbed nitrogen volume showed the Fe-enriched sample. Probably, the present amorphous Fe forms on the clay surface filled the pores and reduced their volume or restrained the gas adsorption into them. The measured isotherms correspond with the Type I of Brunauer-DemingDeming-Teller (BDDT) classification pointing at the presence of micropores [23. Type I isotherms are given by microporous solids having relatively small external surfaces, the limiting uptake being governed by the accessible micropore volume rather than by the internal surface area [18]. The adsorbed volume in the range $0.01-0.2$ probably corresponded with the quasi-multilayer adsorption in supermicropores (larger micropores with diameter approx. 1-2 nm) and the range $p / p_{0}=0.2-0.3$ corresponded with a lower limit of mesopores. Over the relative pressure $p / p_{0}>0.3$ the volume of the adsorbed gas increased moderately for both samples, almost linearly up to $p / p_{0}=0.8$. In general, the hysteresis appearing in the multilayer range of physisorption isotherms is usually associated with the capillary condensation in mesopore structures (pores of widths between 2 and $50 \mathrm{~nm}$ ). Both natural samples also showed a wide hysteresis loop between the adsorption and desorption branch similar to type $\mathrm{H} 4$, according to the IUPAC report, which relates with the presence of mesopores of a slit-like shape.
For the magnetic particles the volume of adsorbed gas increased continuously in the whole range of relative pressure. The hysteresis loop is similar to type $\mathrm{H} 1$ often associated with porous materials known, from other evidence, to consist of agglomerates or compacts of approximately uniform spheres in a fairly regular array, and hence to have narrow distributions of pore size [18]. Considering that the synthetic magnetite belongs to the class of porous materials formed by loose packing, the obtained loop is related with the gas adsorption into the interparticle space of agglomerates.

The experimental data were processed by the $\mathrm{BET}$ isotherm in the range of relative pressure $0.05-0.2 p / p_{0}$ to obtain the value of a specific surface area (Table 2). The BET isotherm showed a convex shape with a negative intercept for both studied clay samples, what indicated again the presence of a higher volume of micropores. From the reason of the negative values of intercept, as well as the $\mathrm{C}_{\mathrm{BET}}$ constant obtained from the mathematic model the values of a specific surface area are not of real physical meaning. These results are in agreement with the previous statements. The BET method is appropriate for meso- to macroporous materials, that is, materials with a pore size above $2 \mathrm{~nm}$. For microporous materials, other data evaluations than BET should be made [24. 
Table 2. Textural parameters of the studied samples determined from the low temperature nitrogen adsorption method

\begin{tabular}{c|cc|c|c|c}
\hline Sample & $\boldsymbol{S}_{\text {BET }^{\prime}} \mathbf{~ m}^{\mathbf{2}} \mathbf{g}$ & $\boldsymbol{C}_{\text {BET }}$ & $\boldsymbol{S}_{\boldsymbol{t}^{\prime}} \mathbf{~ m}^{\mathbf{2}} / \mathbf{g}$ & $\boldsymbol{V}_{\text {tot }^{\prime}} \mathbf{c m}^{\mathbf{3}} / \mathbf{g}$ & $\boldsymbol{V}_{\text {micro }^{\prime}} \mathbf{c m}^{\mathbf{3}} / \mathbf{g}$ \\
\hline FB & 25.2 & -143.8 & 7.2 & 0.0847 & 0.0082 \\
\hline B & 86.5 & -167.7 & 35.0 & 0.1216 & 0.0239 \\
\hline MP & 75.3 & 144.5 & 67.3 & 0.2192 & 0.0033 \\
\hline
\end{tabular}

Therefore, according to the equipment possibilities, the texture of the studied samples was evaluated by the $t$-plot method using the Harkins-Jura isotherm. That allows determination of the micropore volume and value of an external surface area (external surface area + specific surface area of mesopores). The higher micropore volume $V_{\text {micro }}=0.0239 \mathrm{~cm}^{3} / \mathrm{g}$ calculated for the B sample corresponds to a higher position of the adsorption isotherm and a higher value of the specific surface area $S_{\mathrm{BET}}=86.5 \mathrm{~m}^{2} / \mathrm{g}$. But the real surface area, corresponding to the external surface of materials particles, is only $S_{\text {ext }}=35.0 \mathrm{~m}^{2} / \mathrm{g}$. That means that about $20 \%$ of adsorbed nitrogen was concentrated in micropores, while for the FB sample only $10 \%$.

For the MP sample the $S_{\mathrm{BET}}$ value was very close to the $S_{t}$ value, only a small content of micropores should be expected according to the results obtained from the $t$-plot method. This sample showed the highest value of the total pore volume, what corresponds with the measured isotherm.

The pore size distribution curves of the studied samples were calculated using the $\mathrm{BJH}$ method from the desorption isotherms (Fig. 2). The sharp maximum at the distribution curves of clay samples (at about $1.9 \mathrm{~nm}$ ) relates with the skip on the desorption isotherm associated with the socalled forced closure of the hysteresis loop and does not respond to real pores [25]. The $\mathrm{B}$ and $\mathrm{FB}$ samples showed a wider distribution in the range from 4.6 to $19 \mathrm{~nm}$, with a maximum at 6 and $9 \mathrm{~nm}$, respectively. A quite narrow distribution of MP with a Gaussian character and a maximum at $11.4 \mathrm{~nm}$ pointed at the presence of interparticle spaces with a diameter from 3.2 to $24 \mathrm{~nm}$.

\section{As(V) adsorption}

The study of $\mathrm{pH}$ on the sorption capacity of adsorbents for individual ions is important from

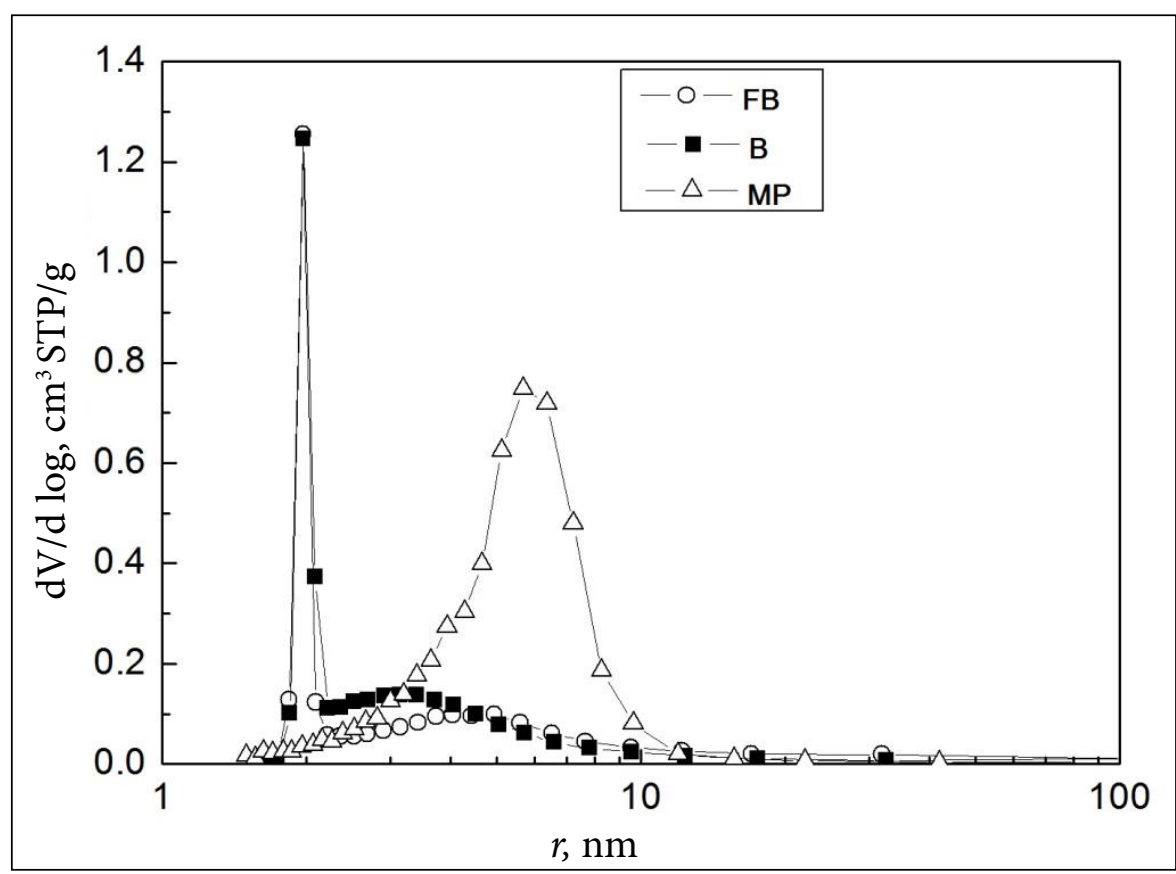

Fig. 2. Pore size distribution curves of the studied bentonite samples and magnetic particles (STP - standard temperature and pressure $-0^{\circ} \mathrm{C}$ and $101325 \mathrm{~Pa}$ ) 
the point of sorption processes. As $(\mathrm{V})$ ions are present in the water solutions in different forms depending on $\mathrm{pH}$ of the solution. Additionally, the value of $\mathrm{pH}$ affected the ionization degree of functional groups, the surface charge of the adsorbent and, finally, the interaction between the metal ions and the adsorbent. In our previous study, the natural bentonite showed the highest equilibrium adsorption capacity at $\mathrm{pH} 4$. As it can be seen from the Zeta potential measurement, the zero point charge of the $\mathrm{B}$ and FB sample is at 4 and 3.5, respectively (Fig. 3). In the solution of lower $\mathrm{pH}$, the dissolution of Fe ions occurs as well as for clay samples as for the magnetic particles. From this reason the batch experiments were performed at $\mathrm{pH} 4$ with the exception of MP higher adsorption capacity.

The clay samples did not show an expressive As(V) uptake in comparison to MP (Fig. A), what corresponds with the result from the zeta potential measurement. Comparing the natural adsorbents, Fe-enriched bentonite showed higher equilibrium adsorption capacity in the solutions with a lower concentration (up to $30 \mathrm{mg} \mathrm{As}(\mathrm{V}) / \mathrm{L}$ ). By increasing of initial ions concentration an expressive ions uptake was observed for the B sample, while for FB the adsorption equilibrium was reached.

Adsorption isotherms are mathematical models which are used for the study of the adsorption

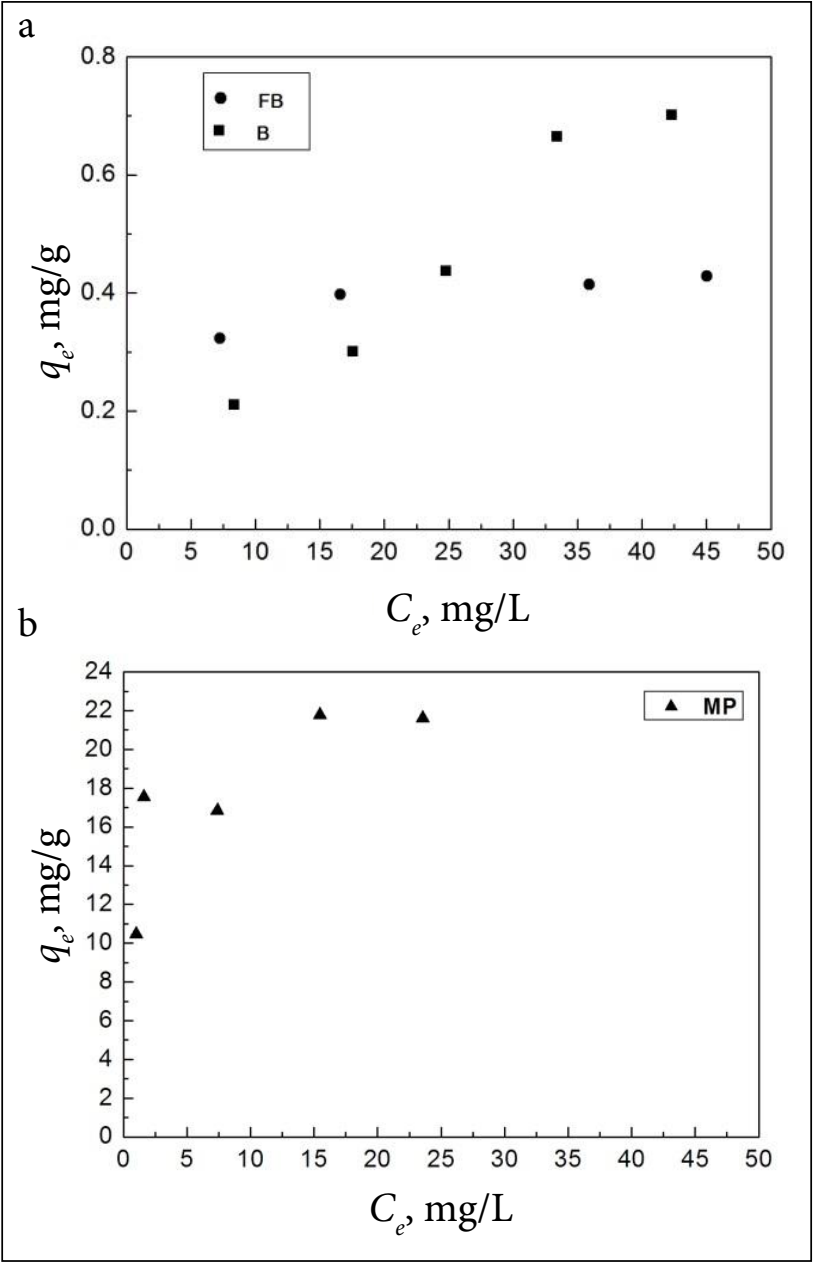

Fig. 4. Adsorption isotherms of the $\mathrm{As}(\mathrm{V})$ adsorption onto the bentonite samples (a) and magnetic particles (b)

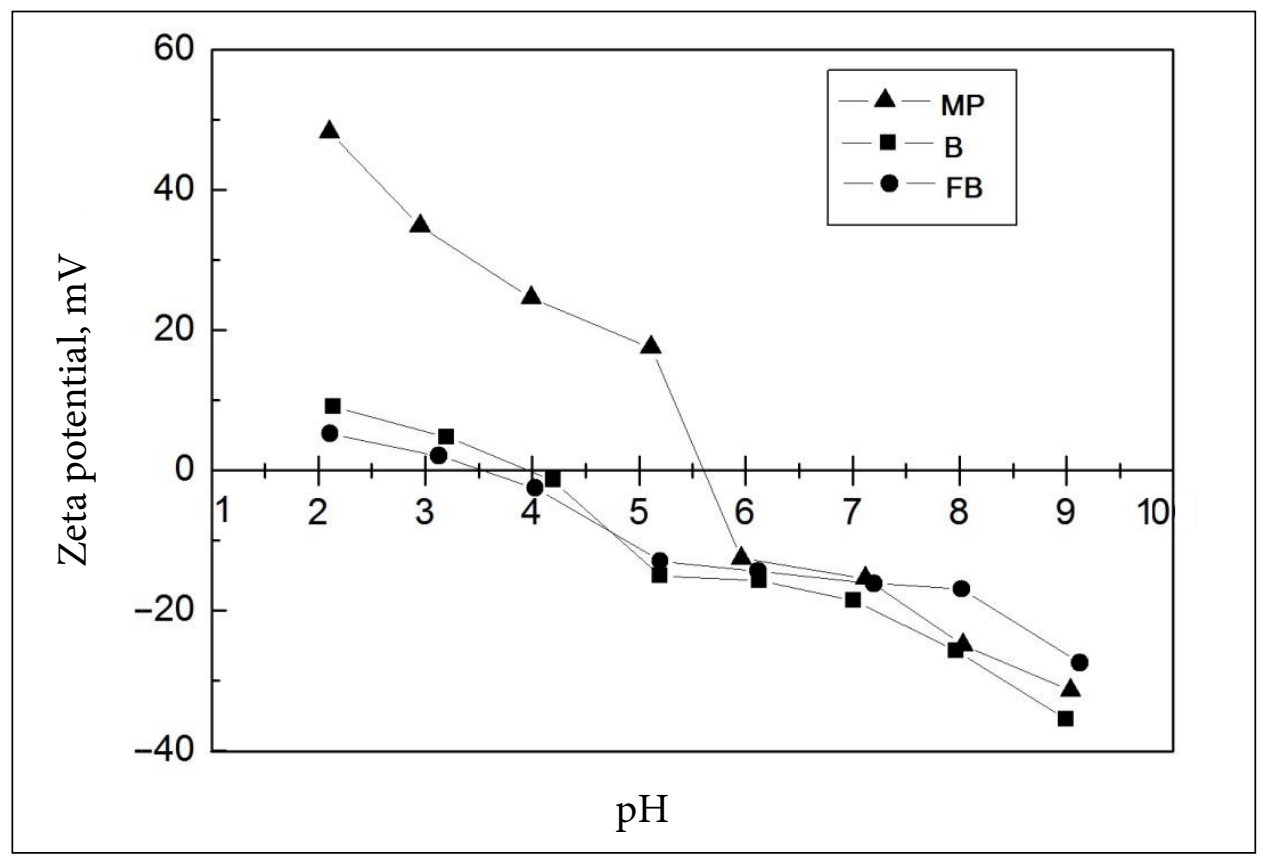

Fig. 3. Zeta potential of the studied bentonite samples and magnetic particles in dependence on $\mathrm{pH}$ 
mechanism and affinity between the adsorbent (with defined surface properties) and adsorption molecules. Two basic models (Langmuir and Freundlich) were applied for the simulation of adsorption isotherms for the studied adsorbents (Fig. 5). The obtained data of the adsorption equilibrium for $\mathrm{As}(\mathrm{V})$ calculated from the linearised Langmuir and Freundlich models are listed in Table 3. From the applied models, the Langmuir better described the adsorption onto the MP and FB sample. The the- oretical value of the maximum sorption capacity equal to $23 \mathrm{mg} \mathrm{As}(\mathrm{V}) / \mathrm{g}$ was calculated for the MP. The natural materials did not show so good adsorption properties towards $\mathrm{As}(\mathrm{V})$ in the batch experiments, they should be used effectively as column fillers to fix finer magnetic particles. On the other hand, whereas the leachates after the soil bioremediation also contain other toxic elements, their selectivity towards $\mathrm{Cu}(\mathrm{II})$ and $\mathrm{Zn}$ (II) ions could be beneficial for the leachates regeneration.
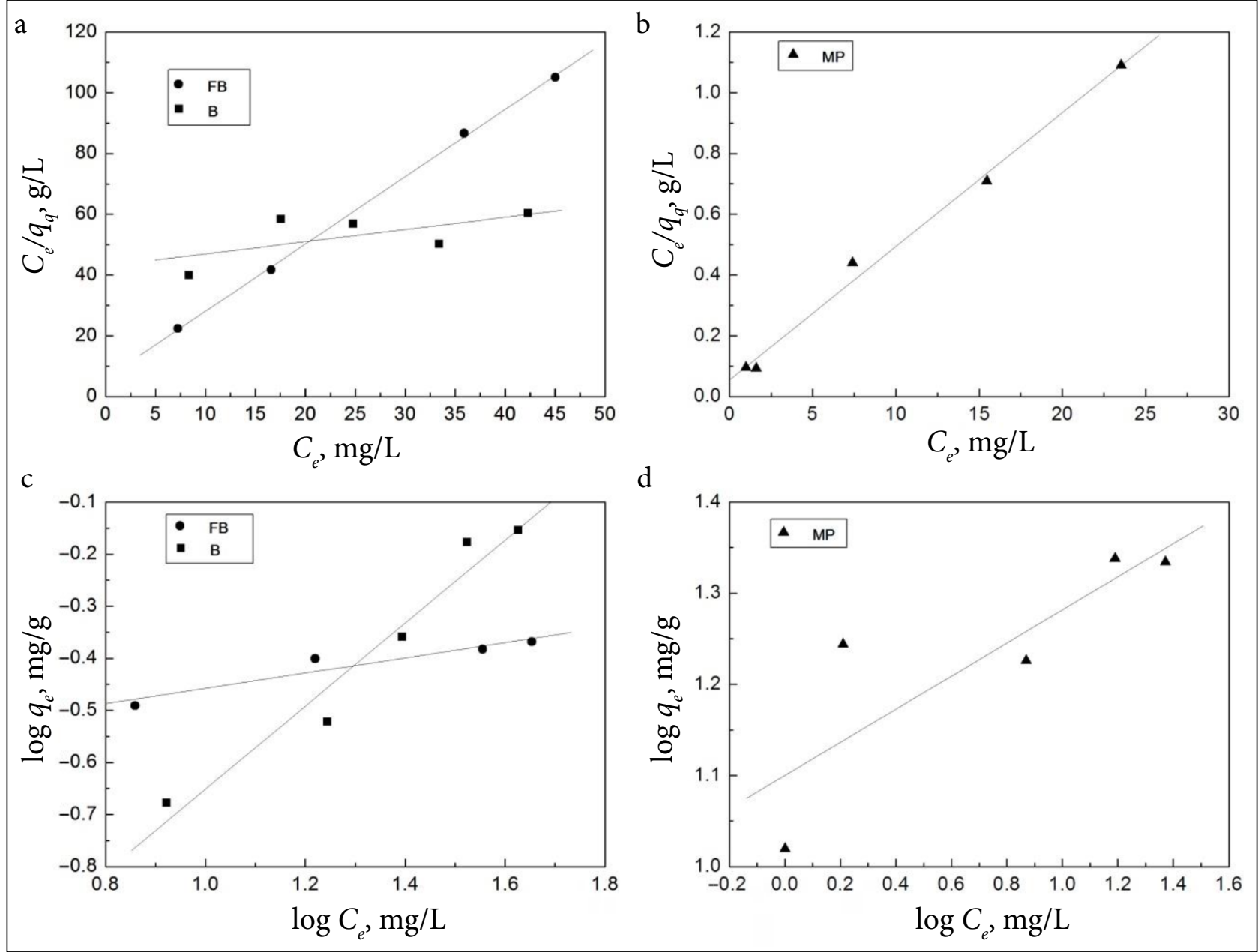

Fig. 5. Linearized Langmuir isotherms of the $\mathrm{As}(\mathrm{V})$ adsorption onto (a) bentonite samples and (b) magnetic particles and linearized Fruendlich isotherms of the $\mathrm{As}(\mathrm{V})$ adsorption onto (c) bentonite samples and (d) magnetic particles

Table 3. Langmuir and Freundlich parameters

\begin{tabular}{c|ccc|c|c|c}
\hline \multirow{2}{*}{ Sample } & \multicolumn{3}{|c|}{ Langmuir parameters } & \multicolumn{3}{c}{ Freundlich parameters } \\
\cline { 2 - 7 } & $\mathbf{Q}_{\mathbf{0}, \mathbf{~} \mathbf{g} / \mathbf{g}}$ & $\mathbf{b}, \mathbf{L} / \mathbf{m g}$ & $\boldsymbol{R}^{\mathbf{2}}$ & $\boldsymbol{K}_{\boldsymbol{f}} \mathbf{L} / \mathbf{g}$ & $\boldsymbol{n}$ & $\boldsymbol{R}^{\mathbf{2}}$ \\
\hline FB & 0.45 & 0.374 & 0.9994 & 0.249 & 0.714 & 0.9073 \\
\hline B & 2.49 & 0.009 & 0.4061 & 0.0356 & 0.160 & 0.9538 \\
\hline MP & 22.73 & 0.818 & 0.9927 & 12.595 & 0.658 & 0.7111 \\
\hline
\end{tabular}




\section{Column study}

Column experiments were performed to study the effect of certain parameters like bedding of samples and their behaviour in columns consisting of different adsorbents as well as of different fractions of natural clay for removal of $\mathrm{As}(\mathrm{V})$ from the aqueous solutions. First, the natural bentonite and $\mathrm{Fe}$-enriched bentonite samples were compared. The model solution with the concentration $30 \mathrm{mg}$ $\mathrm{As}(\mathrm{V}) / \mathrm{L}$ was percolated through the columns twice. After the second cycle, the As(V) concentration was lower than $2 \mathrm{mg} / \mathrm{L}$ for both columns. However, due to the fine particles of the natural samples the percolation was very slow, retarded, and the flow rate was not continual. In the second series, quartz sand and synthetised iron oxide were added into the columns. Quartz sand is a common and suitable material for column study due to its permeability and it is also able to fix the fine clay or magnetic particles in the column. As was shown above, the magnetic particles showed good adsorption properties in batch experiments. They were used as a slim bedding to enhance the $\mathrm{As}(\mathrm{V})$ removal. The columns were filled with $2 \mathrm{~g}$ of $\mathrm{B} / \mathrm{or}$ $\mathrm{FB}$ with a layer of QS and MP (together $5 \mathrm{~g}$ ). Two percolation cycles with solutions of 50 and $100 \mathrm{mg}$ $\mathrm{As}(\mathrm{V}) / \mathrm{L}$ were performed. From this study, more effective was the column filled with B where the $\mathrm{As}(\mathrm{V})$ uptake reached $100 \%$, while the FB sample only $74 \%$ after the second cycle (Fig. 6), against the expectation that the FB sample will be more effective by the reason of a higher $\mathrm{Fe}$ content. Comparing the results obtained from the batch and column experiments it can be concluded that a lower adsorption capacity of the FB sample is caused by the presence of amorphous Fe forms on the clay surface which filled the pores and reduced the potential adsorption sites on the surface. These results correspond with the above-discussed textural analysis, where the B sample also contained a higher volume of micropores and its value of the external surface was higher in comparison with the FB sample.

To differentiate the contribution of particular adsorbents in the column to the As(V) removal, the third series of columns were set. The columns filled with $\mathrm{QS}, \mathrm{QS} / \mathrm{B}, \mathrm{QS} / \mathrm{MP}$ and $\mathrm{QS} / \mathrm{B} / \mathrm{MP}$ were tested and compared. To restrain the column clogging by fine clay particles, a higher fraction of the B sample was used: $0.5-1 \mathrm{~mm}$. Only one cycle with a solution of $100 \mathrm{mg} \mathrm{As}(\mathrm{V}) / \mathrm{L}$ was performed. The column filled with pure QS and QS/B removed only $2.4 \%$ and $5.14 \%$ of $\mathrm{As}(\mathrm{V})$, respectively, the effect of QS/MP was $34.9 \%$. The combination of all studied adsorbents $\mathrm{QS} / \mathrm{B} / \mathrm{MP}$ was most effective in the $A s(\mathrm{~V})$ removal and reached $77.8 \%$ of removed $\mathrm{As}(\mathrm{V})$ (Fig. 7). This is a smaller

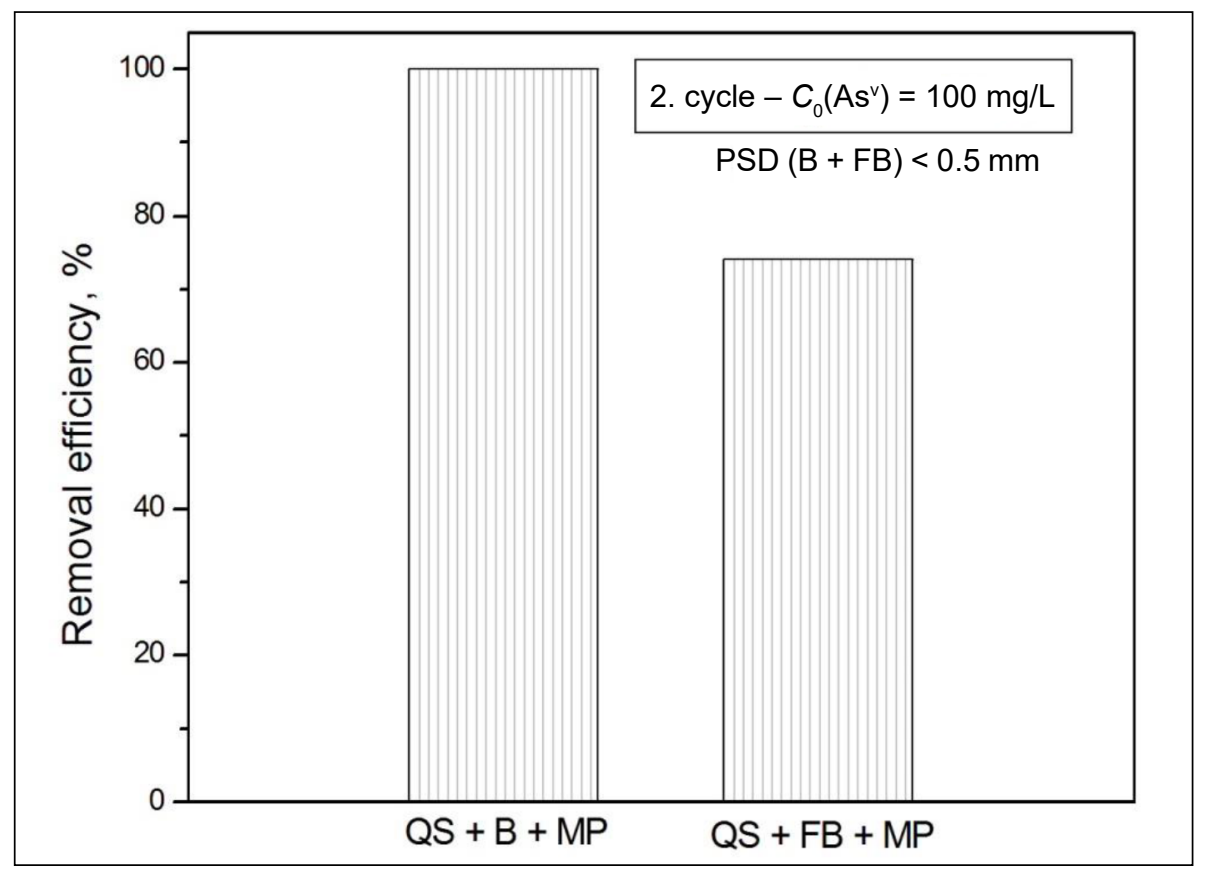

Fig. 6. Effect of the $A s(V)$ adsorption onto the quartz sand/clay samples with the clay fraction $<0.5 \mathrm{~mm}$ and magnetic particles 


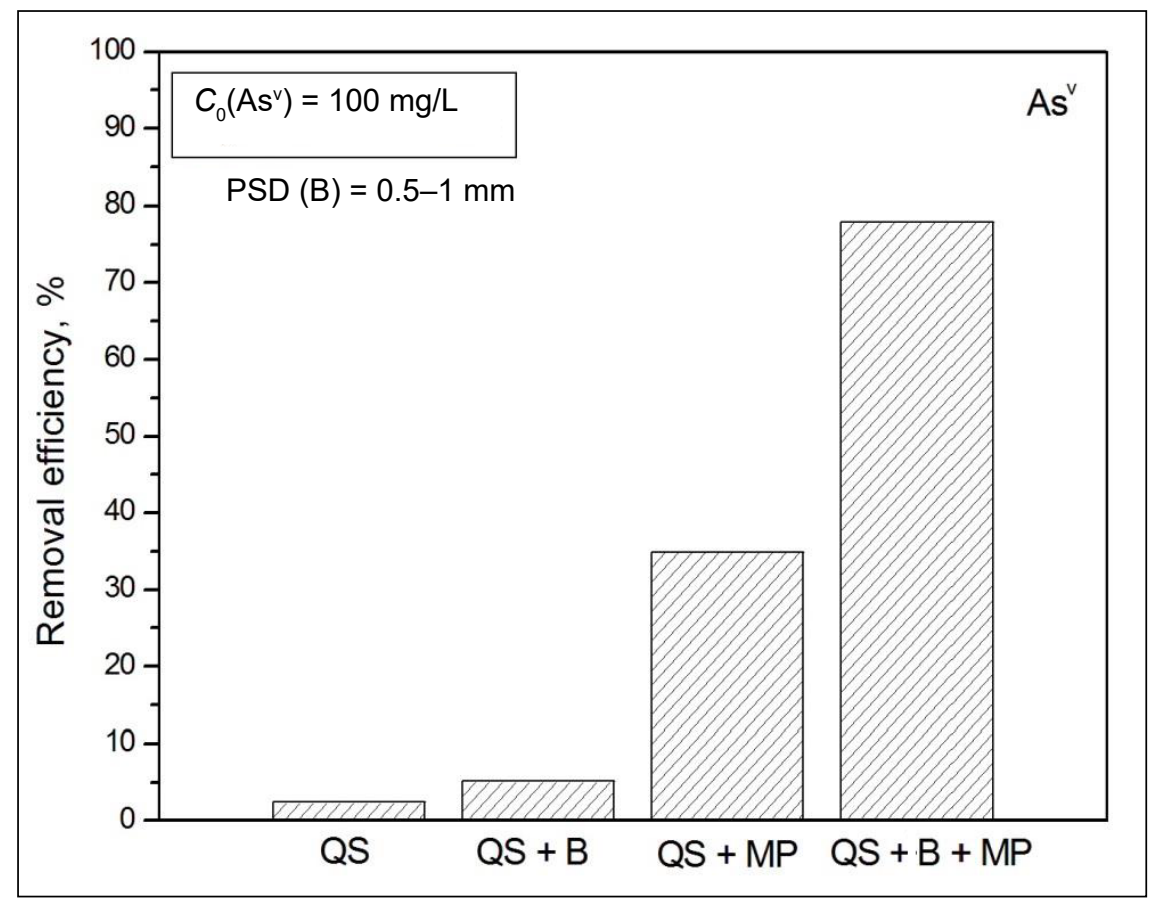

Fig. 7. Effect of the $A s(V)$ adsorption onto particular adsorbents and their combination with the clay particle size $0.5-1 \mathrm{~mm}$

uptake comparing the experiment with a finer B fraction (Fig. 6). On the other hand, the percolation was continual and the column was not clogged. These experiments showed that the particle size is also an important parameter that influences the adsorption properties of studied materials.
Based on the presented results two most effective columns were selected for the second percolation. The solution concentration was $100 \mathrm{mg} \mathrm{As}(\mathrm{V}) / \mathrm{L}$ again. While the adsorption effect of the QS/MP column decreased at $36 \%$, for the QS/B/MP column it was about $24 \%$ (Fig. 8).

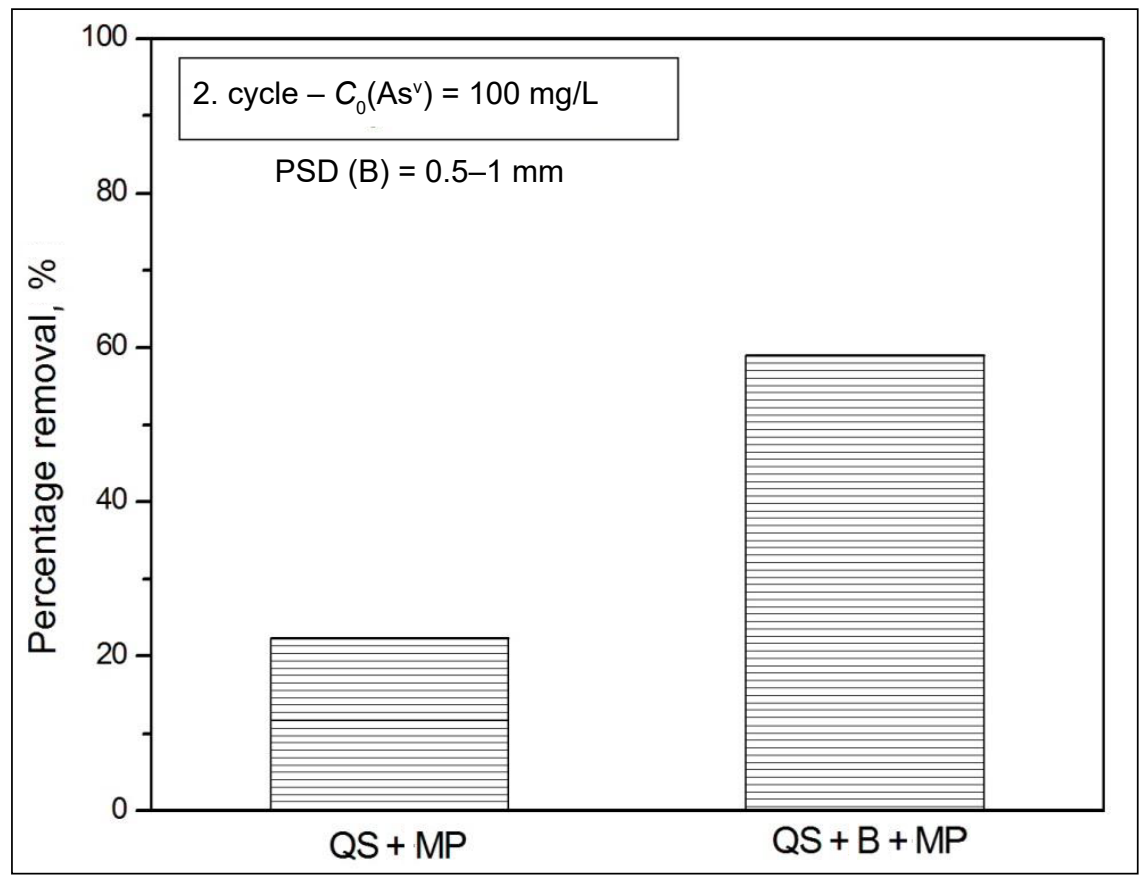

Fig. 8. Effect of the $A s(V)$ adsorption onto the quartz sand/magnetic particles and quartz sand with clay/magnetic particles after the 2 nd cycle of percolation 


\section{CONCLUSIONS}

The adsorption properties of natural bentonite, Feenriched bentonite and synthetised iron oxide towards $\operatorname{As}(\mathrm{V})$ was studied. The batch experiments pointed at the low adsorption capacity of natural materials. The natural bentonite sample was more effective in the $\mathrm{As}(\mathrm{V})$ removal as compared to $\mathrm{Fe}$ rich bentonite, showed a higher volume of micropores and a higher value of the external surface area. The best adsorption properties towards As $(\mathrm{V})$ showed synthetised magnetic particles. The column studies performed by different type of beddings indicated that the particle size is an important factor and influences the adsorption capacity of bentonite. The column filled with QS/B/MP with a particle size of bentonite below $0.5 \mathrm{~mm}$ removed $100 \%$ of $\mathrm{As}(\mathrm{V})$, while the column with a particle size of bentonite between $0.5-1 \mathrm{~mm}$ reached $77.8 \%$ of $\mathrm{As}(\mathrm{V})$ uptake in the first cycle. On the other hand, a fine fraction of bentonite affected the clogging of the column and flow continuity. These introductory experiments proved that it is suitable to combine the clay adsorbents with natural materials such as quartz sand as fillers in columns because of their permeability as well as to fix finer magnetic particles to enhance the column effect in $\mathrm{As}(\mathrm{V})$ removal. Additionally, natural clays were proved as good adsorbents of other toxic elements such as $\mathrm{Cu}$ (II) and $\mathrm{Zn}$ (II) [26]. The combination of quartz sand, clays and magnetic particles in the column beddings was most effective also after the 2nd percolation of the media of higher $\mathrm{As}(\mathrm{V})$ concentration. A clay filler could be an advantage in the treatment of leachates containing also $\mathrm{Cu}$ (II) and $\mathrm{Zn}$ (II) from the contaminated soil after the bioremediation process.

\section{ACKNOWLEDGEMENTS}

The authors are thankful for financial support of the Grant Agency of the Slovak Republic VEGA for Project No. 2/0029/19.

Received 29 November 2018 Accepted 17 January 2019

\section{References}

1. C. Garbisu, I. Alkorta, Eur. J. Miner. Process. Environ. Prot., 3(1), 58 (2003).

2. D. Štyriaková, I. Štyriaková, I. Štyriak, J. Šuba, Z. Danková, D. Gešperová, Procedia Earth Planet. Sci. 15, 866 (2015).
3. I. Štyriaková, I. Štyriak, A. Balestrazzi, C. Calvio, M. Faé, D. Štyriaková, Soil Sediment Contam., 25(5), 519 (2016).

4. D. Štyriaková, I. Štyriaková, J. Šuba, I. Štyriak, Int. J. Agric. Environ. Res., 2(10), 88 (2016).

5. I. Štyriaková, D. Štyriaková, A. Bekényiová, J. Šuba, Solid State Phenom., 262, 634 (2017).

6. M. Galamboš, O. Rosskopfová, J. Kufčáková, P. Rajec, J. Radioanal. Nucl. Chem., 288, 765 (2011).

7. M. Galamboš, M. Daňo, O. Rosskopfová, et al., J. Radioanal. Nucl. Chem., 292, 481 (2012).

8. M. Galamboš, M. Magula, M. Daňo, M. Osacký, O. Rosskopfová, P. Rajec, J. Radioanal. Nucl. Chem., 293, 829 (2012).

9. M. Galamboš, M. Osacký, O. Rosskopfová, A. Krajňák, P. Rajec, J. Radioanal. Nucl. Chem., 293, 889 (2012).

10. M. Galamboš, A. Krajňák, O. Rosskopfová, E. Viglašová, R. Adamcová, P. Rajec, J. Radioanal. Nucl. Chem., 298, 1031 (2013).

11. O. Rosskopfová, L. Pivarčiová, A. Krajňák, M. Galamboš, P. Rajec, J. Radioanal. Nucl. Chem., 307, 179 (2016).

12. S. Andrejkovičová, M. Pentrák, L. Jankovič, P. Komadel, Geol. Carpath., 61, 163 (2010).

13. L. Pivarčiová, A. Krajňák, O. Rosskopfová, M. Galamboš, P. Rajec, J. Radioanal. Nucl. Chem., 304, 851 (2015).

14. A. Krajňák, L. Pivarčiová, O. Rosskopfová, M. Galamboš, P. Rajec, J. Radioanal. Nucl. Chem., 304, 587 (2015).

15. Z. S. Kooner, Environ. Geol., 21, 242 (1993).

16. N. D. Pragnesh, V. Ch. Lakhan, J. Nanotechnol., Article ID 398569 (2014).

17. A. Bekényiová, I. Štyriaková, Z. Danková, Archives Technic. Sci., 12(1), 59 (2015).

18. K. S. W. Sing, D. H. Everest, R. A. W. Haul, et al., Pure Appl. Chem., 57, 603 (1985).

19. J. D. Boer, B. Lippens, B. Linsen, J. Broekhoff, A. V. D. Heuvel, T. J. Osinga, J. Colloid Interface Sci., 21, 405 (1966).

20. E. P. Barrett, L. G. Joyner, P. P. Halenda, J. Am. Chem. Soc., 73, 373 (1951).

21. R. Bowell, Appl. Geochem., 9, 279 (1994).

22. Y. Jeong. M. Fan, S. Singh, Ch. L. Chuang, B. Saha, J. H. Van Leewen, Chem. Eng. Proc., 46, 1030 (2007).

23. S. Brunauer, P. H. Emmett, E. Teller, J. Am. Chem. Soc., 60, 309 (1938).

24. P. Rajec, M. Galamboš, M. Daňo, et al., J. Radioanal. Nucl. Chem., 303, 277 (2015).

25. P. Hudec, Texture of Solids. Characterization of Adsorbents and Catalysts by Physical Nitrogen Adsorption, 1st edn., Slovak University of Technology, Bratislava (2012) [in Slovak].

26. A. Bekényiová, Z. Danková, I. Štyriaková, E. Fedorová, B. Doušová, Proceedings of the 4th International Scientific Conference Biotechnology \& Metals, Košice (2016). 
Zuzana Danková, Alexandra Bekényiová, Zdenka Lukáčová-Bujňáková, Zuzana Mitroová, Danka Gešperová, Iveta Štyriaková, Darina Štyriaková, Jaroslav Briančin, Jana Tomčová

\section{EKSPERIMENTINIS As(V) ADSORBCIJOS ANT} SKIRTINGŲ NEŠĖJŲ TYRIMAS

Santrauka

Tirta As(V) adsorbcija iš vandeninių tirpalų ant gamtinio bentonito $(\mathrm{B})$, geležimi praturtinto gamtinio bentonito (FB) ir sintetinių magnetinių dalelių (MP). Nustatyta, kad stacionariomis adsorbcijos sąlygomis MP yra našesnis adsorbentas už abu gamtinius adsorbentus. Didžiausia jo adsorbcijos geba siekia $23 \mathrm{mg} / \mathrm{g}$. Kita vertus, adsorbcijos kolonèlejje sąlygomis visi tirtieji adsorbentai pasižymėjo panašaus dydžio adsorbcine geba. 